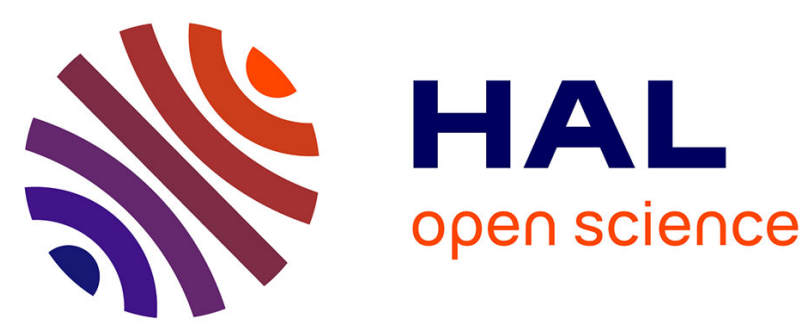

\title{
Physical, morphological and chemical modification of Al-based nanofillers in by-products of incinerated nanocomposites and related biological outcome
}

\author{
C. Chivas-Joly, C. Longuet, J. Pourchez, L. Leclerc, G. Sarry, José-Marie
} Lopez-Cuesta

\section{To cite this version:}

C. Chivas-Joly, C. Longuet, J. Pourchez, L. Leclerc, G. Sarry, et al.. Physical, morphological and chemical modification of Al-based nanofillers in by-products of incinerated nanocomposites and related biological outcome. Journal of Hazardous Materials, 2019, 365, pp.405-412. 10.1016/j.jhazmat.2018.10.029 . hal-02080283

\section{HAL Id: hal-02080283 https://hal.science/hal-02080283}

Submitted on 25 May 2021

HAL is a multi-disciplinary open access archive for the deposit and dissemination of scientific research documents, whether they are published or not. The documents may come from teaching and research institutions in France or abroad, or from public or private research centers.
L'archive ouverte pluridisciplinaire HAL, est destinée au dépôt et à la diffusion de documents scientifiques de niveau recherche, publiés ou non, émanant des établissements d'enseignement et de recherche français ou étrangers, des laboratoires publics ou privés. 


\title{
Physical, morphological and chemical modification of Al-based nanofillers in by-products of incinerated nanocomposites and related biological outcome
}

\author{
C. Chivas-Joly ${ }^{\mathrm{a}, *}$, C. Longuet ${ }^{\mathrm{b}}$, J. Pourchez $^{\mathrm{c}}$, L. Leclerc ${ }^{\mathrm{c}}$, G. Sarry ${ }^{\mathrm{c}}$, J-M. Lopez-Cuesta $^{\mathrm{b}}$ \\ ${ }^{\mathrm{a}}$ LNE, 29 Avenue Roger Hennequin, 78197 Trappes Cedex, France \\ ${ }^{\mathrm{b}}$ C2MA, Ecole des Mines d'Alès, 6 Avenue de Clavières, 30319 Alès Cedex, France \\ ${ }^{\mathrm{c}}$ Univ. Lyon, IMT Mines Saint-Etienne, Centre CIS, INSERM, SainBioSE, F-42023 Saint-Etienne, France
}

\section{A B S T R A C T}

The number of products containing nanomaterials is increasing this last ten years. Information and literature about the end-of-life of nanocomposites often remains partial and does not address the overall fate and trans-formations of nanoparticles that may affect biological responses. This paper underlines that the physico-chemical features of nanoparticles can be modified by the incineration process and the available toxicological data on pristine nanofillers might not be relevant to assess the modified nanoparticles included in soot. Combustion tests have been performed at lab-scale using a cone calorimeter modified to collect fumes (particulate matter and gas phase) and have been characterized using various techniques. Nanocomposites selected were poly(ethylene vinyl acetate) containing Al-based nanoparticles, i.e. boehmites or alumina. Evaluations of in vitro cytotoxicity re-sponses on pristine nanofillers, soot and residual ash, show that safe boehmite nanoparticles, become toxic due to a chemical modification after incineration process.

G R A P H I C A L A B S T R A C T

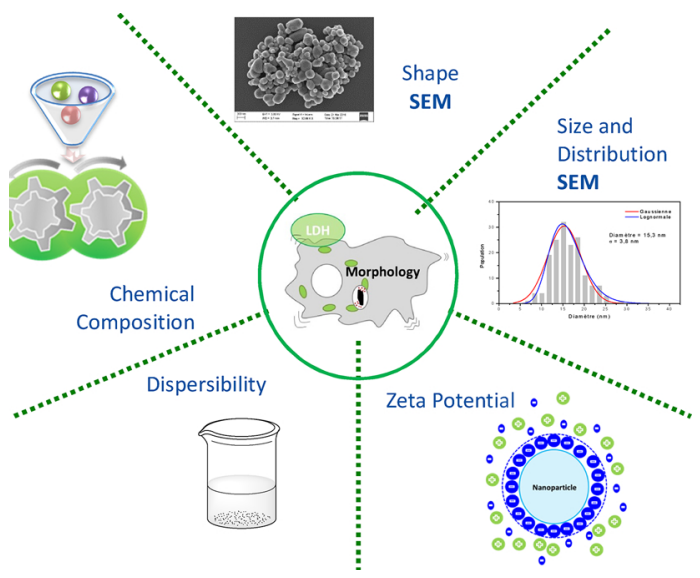

Keywords:

Cytotoxicity

Incineration

Nanocomposite

Aerosol and residues

\footnotetext{
* Corresponding author.

E-mail address: carine.chivas-joly@lne.fr (C. Chivas-Joly).
} 


\section{Introduction}

Recently, nanomaterials have become an ever-increasing feature on the market [1], with applications like mechanical strengthening, coloring, fire-proofing or chemical catalysis. These applications are linked to the specific properties (size, shape, surface area) of nanoparticles. However, the specific properties of nanoparticles also imply that they may represent a risk for human health or the environment. Their size allows them to cross biological barriers [2], and their reactivity can lead to adverse health effects $[3,4]$. The risk assessment led to a large amount of studies on the toxicity of nanoparticles, too often with conflicting results [5] as the biological behavior of nanoparticles can be very difficult to understand and thus to predict. It is therefore needed to perform a very thorough an accurate characterization of the nanoparticles' features before carrying out toxicological assessment, as recommended by ISO/TR 13,014 guidelines [6].

Organization for Economic Co-operation and Development (OECD) recently published a report [7] dealing with the amount of nanomaterials entering each type of waste treatment facility and the associated risks of human and environmental exposure. This report pointed at a general lack of knowledge on the fate of nanoparticles during waste management. On the specific field of incineration, one of the main questions was the efficiency of flue gas treatments for the removal of nanoparticles [8]. Previous works $[9,10]$ showed that some nanoparticles can escape destruction in waste incinerator or trapping in the incineration plant's flue gas treatment system. However, the physicochemical features as well as the hazard of nanoparticles can be modified by the incineration process [11], and the available toxicological data (based on nanoparticles as produced which are initially introduced into the manufactured products) might not be relevant to the modified nanoparticles included in soot. It is indeed possible that a non-toxic or weakly toxic nanoparticle can be transformed and become more toxic after changes due to incineration conditions.

The literature is limited on the thermal degradation process of nanoenable products. Sotiriou et al. [12] underline the brittle residual ash and raised the question of potential release of nanofillers in environment. Vejerano et al. [13] focused on waste containing nanomaterials through lab-scale incineration. The authors noted that the majority of nanoparticles were found in residual ash. Singh, [14] using an incinerator facility presented the key factors governing the release of nanofillers such as temperature, nanofillers loading. Finally, Ounoughene et al. [15] highlighted the necessity to develop analytic tools in order to quantify the nanostructure in the waste, in the residues and in the aerosol.

Moreover, very little is known on the potential physical, chemical and morphological transformation of nanomaterials during the incineration process of nano-enable products. The present study focuses particularly on nanocomposites since in the last years, inorganic fillers have been widely incorporated in polymer matrix to improve mechanical properties or fire behavior. Some works reported on emission of pollutants resulting from accidental fire of nanocomposites [16,17] or focused on smoke characterization and fire toxicity [18], whereas, few studies dealt with the evaluation of particle size and concentration of the released aerosol from the thermal decomposition of nanocomposites [19,20]. Some works stressed on the effect of nanofillers loading and also on the temperature of the combustion [21-23], which can affect the fate and the possible transformation of the nano-objects initially incorporated in the polymer matrix, when they are not destroyed during incineration.

All things considered, there is a lack of a fundamental understanding on the thermal decomposition of nanocomposites. More specifically, some key points should be deeply investigated such as the physical, chemical and morphological changes of nanofillers during the incineration process, their release as components of by-products (i.e. soot and residual ash), and finally the hazard associated to these byproducts. Therefore, this work aims at providing original data in term of the identification of nanofillers modification and their related hazard during the thermal degradation of industrial nanocomposites.

The in vitro cellular response was assessed using a macrophage cell line in terms of cytotoxicity (i.e. quantification of LDH release). This cytotoxicological response was considered regarding the physico-chemical parameters defined by ISO standards.

We focused on nanocomposites relevant of the wire and cable industry, i.e. ethylene vinyl acetate (EVA) nano-enabled thermoplastics incorporating Aluminium-based nanofillers (alumina and boehmites) incorporated into a poly(ethylene vinyl acetate) (noted EVA) matrix. Indeed, EVA-based composites are frequently filled with Al-based nanosized particles in order to significantly improve mechanical properties and fire reaction.

\section{Materials and methods}

\subsection{Sample's description and formulations}

The Poly(ethylene vinylacetate) used is Repsol EVA PA 440 from Gazechim. Alumina nanoparticles were purchased from Evonick (AluC) and two boehmites have been given by Saint Gobain. The boehmite were selected with varying shape platelet or spherical, boehmite; AlO $(\mathrm{OH})$-p vs. $\mathrm{AlO}(\mathrm{OH})-\mathrm{s})$. The first step to facilitate the formulation implementation was the preparation of EVA solution in tetrahydrofurane (THF) at $50^{\circ} \mathrm{C}$ before particles dispersion using a magnetic stirrer. After THF evaporation composite master batch film was collected and crushed. Then the master batches were diluted using a twin-screw extruder. The melt blending was carried out on a co-rotating twin-screw extruder (Clextral, standard profile, length $=1200 \mathrm{~mm}$, speed $=200$ $\mathrm{rpm}$, screw diameter $=20 \mathrm{~mm}, \mathrm{~T}=120^{\circ} \mathrm{C}$ to $170^{\circ} \mathrm{C}$ and rate flow $=$ $9 \mathrm{~kg} / \mathrm{h}$ ). The samples were injection molded (Krauss Maffei KM $50 \mathrm{t}$, $\mathrm{T}=170-180^{\circ} \mathrm{C}$, mold temperature $=25^{\circ} \mathrm{C}$ ) to obtain specimens $\left(100 \times 100 \times 4 \mathrm{~mm}^{3}\right)$. Sample pellets were dried at $70^{\circ} \mathrm{C}$ for $8 \mathrm{~h}$ before injection molding.

\subsection{Lab-scale incineration process and sampling soot and residual ash for analysis}

Experiments are performed using a lab-scale incineration facility mainly composed of a modified a cone calorimeter with controlled atmosphere. These device was developed, validated and compared in a previous work [22,24]. The combustion parameters are well-controlled in terms of temperature $\left(850^{\circ} \mathrm{C}\right.$ in the combustion and post-combustion zone), residence time (at least two seconds in the post combustion zone at $850^{\circ} \mathrm{C}$ ), atmosphere (air-excess, never below $11 \%$ of oxygen) and flow turbulence (with a mixture between combustible and oxygen). The heat flux was fixed at $75 \mathrm{~kW} \cdot \mathrm{m}^{-2}$ on the sample $(2.5 \mathrm{~g})$ embedded in a fine inconel grid. The aerosol combustion was sampled with an isoprobe (insulated at $150^{\circ} \mathrm{C}$ ) especially design for keeping isokinetic in the duct. The total amount of aerosol was deposited on $47 \mathrm{~mm}$ diameter polycarbonate membranes (Isopore $0.2 \mu \mathrm{m}$ GTTP- Merck Millipore) (Fig. 1).

It was noticed that aerosols from the incineration of nanocomposites consisted of a complex mixture of particles called soot or particulate matter (PM). During incineration process, the residual ash collected contained very different products such as, fly ash and bottom ash.

For the toxicological assessment, soot and residual ash from incineration were dispersed to obtain a stock suspension at a concentration of $12 \mathrm{mg} / 100 \mathrm{~mL}$ in water milliQ. This dispersion requires the establishment of a specific protocol in view of the constraints associated with the presence of carbonaceous soot, more or less oily, or with a liquid phase modifying the local state of aggregation of particles. Firstly, a 30-minutes sonication at a power of $70 \mathrm{~W}$, (using an ultrasonic bath) was performed to remove all particles from filters used for the collection of the soot. To avoid agglomeration and to obtain a stable suspension, the suspension was then sonicated using a Bioblock 


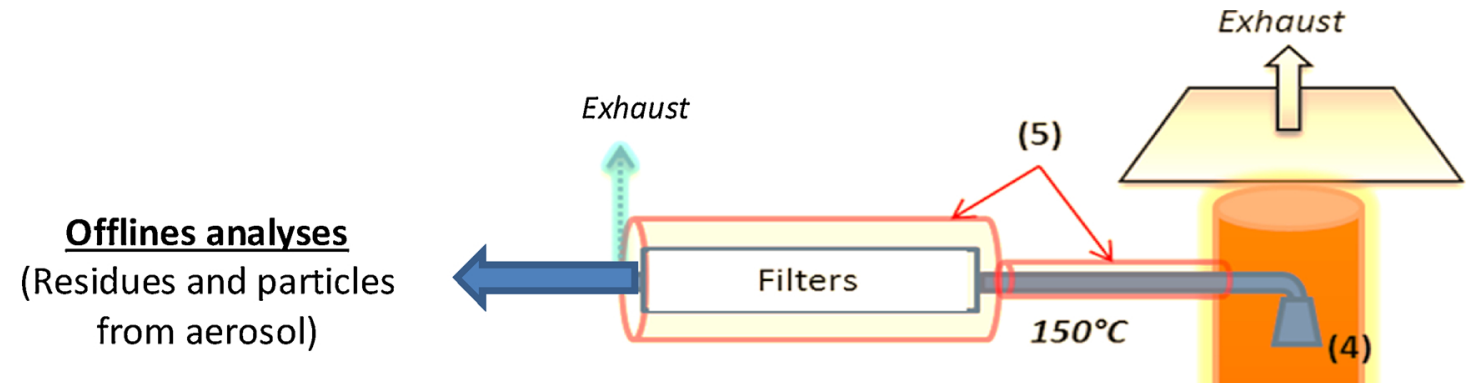

(1) Box with controlled atmosphere

(2) Sample on inconel grid

(3) Temperature $850^{\circ} \mathrm{C}$

(4) Chimney (320 $\mathrm{mm}$ long steel pipe transfer section)

(5) Electrical heating system to maintain control on the flow temperature to avoid condensation

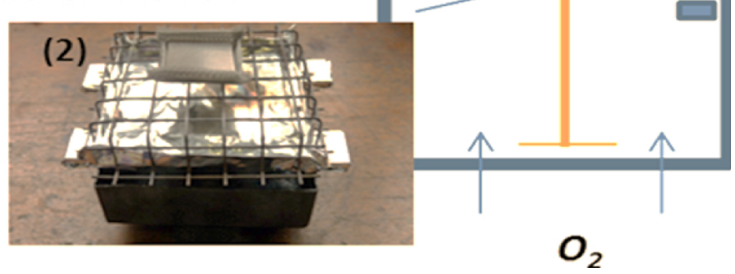

Fig. 1. Lab-scale incinerator (cone calorimeter with controlled atmosphere according to G. Ounoughene et al. 2015).

Scientific Vibracell 75,043 probe-sonicator (750 W) for $10 \mathrm{~s}$ and $20 \mathrm{~s}$ pause, for $40 \mathrm{~min}$ in total. The same protocol was kept for final dilution in the biological medium.

\subsection{Physical, chemical and morphological characterization}

\subsubsection{Thermogravimetric analysis (TGA)}

The thermal decomposition was investigated using a Perkin Elmer Pyris $^{-1}$ TGA. All measurements were performed under air with a heating rate of $10^{\circ} \mathrm{C}$ min- 1 , from $30^{\circ} \mathrm{C}$ to $900{ }^{\circ} \mathrm{C}$. The sample weight was $10 \pm 2 \mathrm{mg}$.

\subsection{2. $X$-Ray diffraction}

X-Ray Diffraction (XRD) analyses of nanoparticles were performed on a Bruker X-ray diffractometer using $\mathrm{Cu}$ Ka radiation.

\subsubsection{Zeta potential measurement}

The optimal dispersion of nanoparticles on a substrate depends on zeta potential of the initial suspension. The nanoparticles are well dispersed when the suspension is stable and then absolute value of the zeta potential is higher than $30 \mathrm{mV}$. For each sample, the measurements of zeta potential as a function of $\mathrm{pH}$ were carried out by keeping constant ionic strength with sodium perchlorate solution, perchloric acid and sodium hydroxide of concentration $0.1 \mathrm{~mol} / \mathrm{L}$.

\subsubsection{SEM measurements}

SEM images have been performed with a Zeiss ULTRA-Plus equipped of a Field Emission Gun (FEG) microscope and in-Lens SE detector. All images have been carried out through secondary electrons collected by InLens detector. Size of particles have been determined and this measurand (area-equivalent diameter, $\mathrm{D}_{\text {area-eq.) }}$ ), is defined as the diameter of a sphere that would have a projected surface.

\subsection{Cytotoxicity assessment}

\subsubsection{Cell line and culture conditions}

The RAW 264.7 were provided by the ATCC Cell Biology Collection (Promochem LGC). This murine peritoneal macrophages cell line is transformed by the Abelson Murine Leukemia Virus. Incubation of cells were performed at $37^{\circ} \mathrm{C}$ under a $5 \%$ carbon dioxide humidified atmosphere using Dulbecco's Modified Eagle's Medium (DMEM, Invitrogen). This medium was complemented (DMEMc) with $10 \%$ of fetal calf serum (FCS, Invitrogen), 1\% penicillin-streptomycin (penicillin 10000 units/ $\mathrm{mL}$, streptomycin $10 \mathrm{mg} / \mathrm{mL}$; Sigma-Aldrich). Cell viability was checked by trypan blue dye exclusion (Sigma). We used the protocol previously described by Leclerc et al. [25,26]. Cells were prepared in 96-well plates. A nanoparticle stock suspension of $1200 \mu \mathrm{g} / \mathrm{mL}$ in water milliQ was prepared in order to perform dilutions in DMEMc. These dilutions were then added to the cell culture wells. Different doses of nanoparticles were tested: $11.25,22.5,45$ and $90 \mu \mathrm{g}$ of nanoparticles per $\mathrm{mL}$. Three independent experiments were performed for each condition.

\subsubsection{Cytotoxicity assay}

The release of lactate dehydrogenase (LDH) in the culture supernatant, after a $24 \mathrm{H}$ incubation, lead to assess the damage of cell membranes in presence of nanoparticles. The CytoTox-ONE ${ }^{\mathrm{TM}}$ Homogeneous Membrane Integrity Assay (Promega) was purchased, in order to dose LDH using a fluorometer (Fluoroskan Ascent, Thermolabsystems) with excitation/emission wavelengths set at 530/ $590 \mathrm{~nm}$. The positive control consists in measuring the released LDH after the lysis of control cells, this level of LDH corresponding to $100 \%$ of cytotoxicity. Finally, the activity of the released LDH for the different experimental conditions was expressed as a percentage of this positive control. 

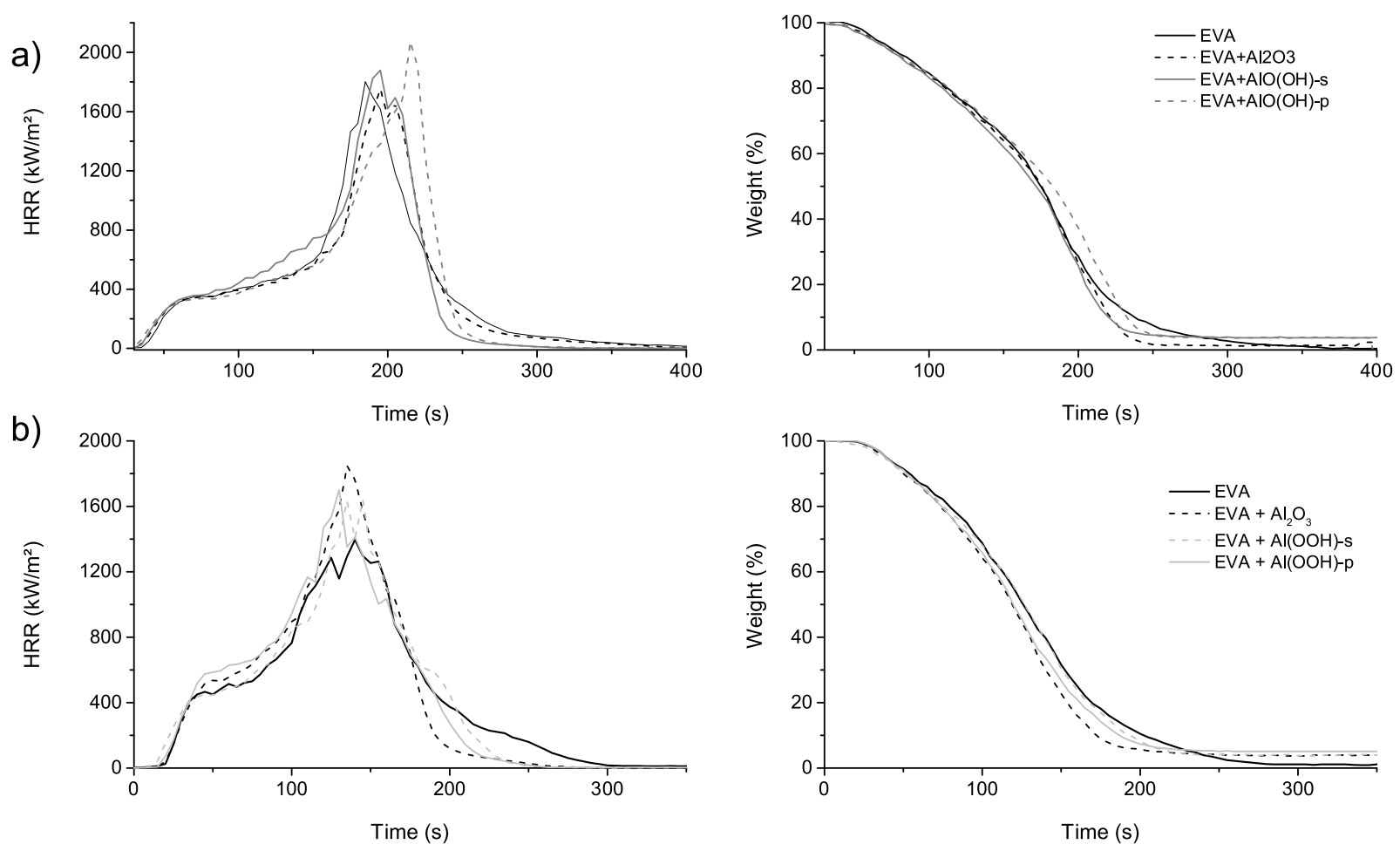

Fig. 2. Cone calorimeter test (a) in fire condition at $50 \mathrm{~kW} \cdot \mathrm{m}^{-2}$ and (b) in incineration condition at $75 \mathrm{~kW} \cdot \mathrm{m}^{-2}$.

\section{Results and discussion}

\subsection{Thermal stability degradation}

Fire behaviour of pure polymer and nanocomposites was investigated using a cone calorimeter with an incident irradiance of $50 \mathrm{~kW} / \mathrm{m}^{2}$ and incineration with heat flux fixed at $75 \mathrm{~kW} / \mathrm{m} 2$. The cone calorimeter test permits to assess the fire behaviour and to determine the weight loss of neat EVA and EVA nanocomposites (Fig. 2).

In incineration condition, specimens containing alumina, boehmites $(\mathrm{AlO}(\mathrm{OH})-\mathrm{s}$ and $\mathrm{AlO}(\mathrm{OH})-\mathrm{p})$ have shown an increase of peak heat release rate. These particles impaired the fire behaviour of neat EVA. The residue increase was only due to the substitution of a part of polymer by inorganic particles.

In order to characterize the thermal stability of the neat EVA and EVA nanocomposites thermogravimetric analyses (TGA) have been performed. Unlike the cone calorimeter no difference between the neat EVA and the EVA composites except at the end of test were noted for the same reasons as outlined for cone calorimeter tests. The difference rate of residue between neat EVA and EVA based nanoparticles is mainly due to the presence of nanoparticles during the degradation process (Fig. 3). Moreover, few organic carbon is detectable in the residual ash from EVA based nanocomposites.

In order to focus on the end of life of nanocomposites and to investigate the possible release of PM by sampling aerosols. The following part devoted to the study of the morphological analysis of soot and residual ash. The physical and morphological transformation of released PM and residual ash will be investigated in the following section. Finally, the nanoparticles effect on biological outcome will be determined.

\subsection{Chemical, physical and morphological transformation of nanofillers in soot and residual ash}

Fig. 4 shows the SEM images regarding the fate of nanoparticles (in soot and/or residual ash) after incineration of EVA nanocomposites.

The irradiation use in incineration simulation test $\left(75 \mathrm{~kW} / \mathrm{m}^{2}\right)$ is

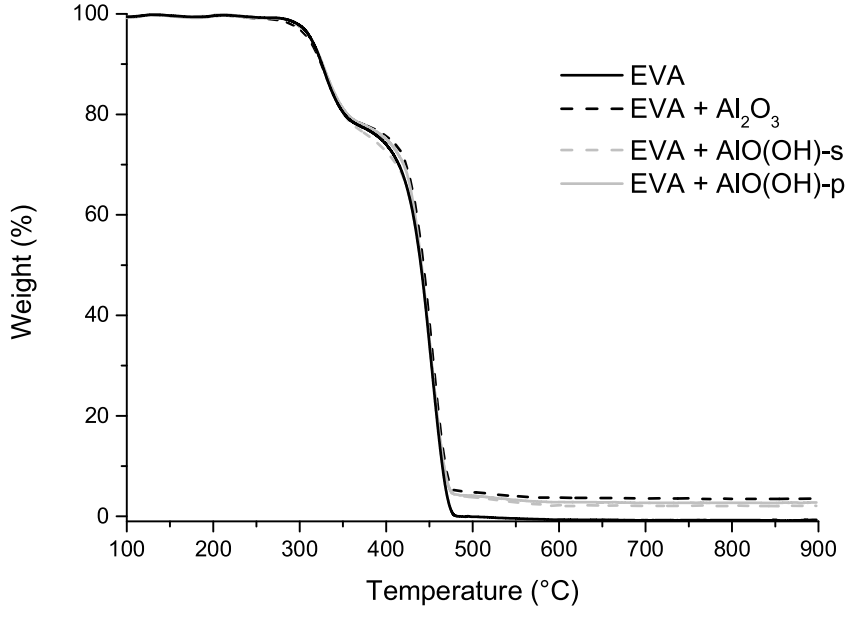

Fig. 3. TGA measurements of EVA composites.

equivalent to $850^{\circ} \mathrm{C}$, and the full decomposition of EVA is at around $480^{\circ} \mathrm{C}$ that leading to no residue only soot could be observed. Then, EVA burns quickly and generates a high smoke emission without leaving any char residues during incineration process (Fig. 5).

This is probably attributed to the full decomposition of EVA at $480^{\circ} \mathrm{C}$ (Fig. 3), leading to no residue. The morphology of soot of EVAbased nanocomposite is quite similar to pristine EVA. While the soot of pristine EVA consists in an agglomerated structure with pseudo-spherical nanoparticles, the presence of boehmite and alumina doesn't lead to significant modifications of the soot structure. The XRD analysis (Fig. 6) confirmed that there are no nanofillers detectable inside the soot. Moreover, the presence of nanofillers doesn't seem to increase the soot production during the matrix thermal decomposition.

Then, knowing the burning way of EVA, it seems that the phenomenon speed might induce the presence of nanoparticles in residue. This seems to be confirmed by the TGA measurement where the yields of residue is closed to the percentage introduce in the nanocomposite 


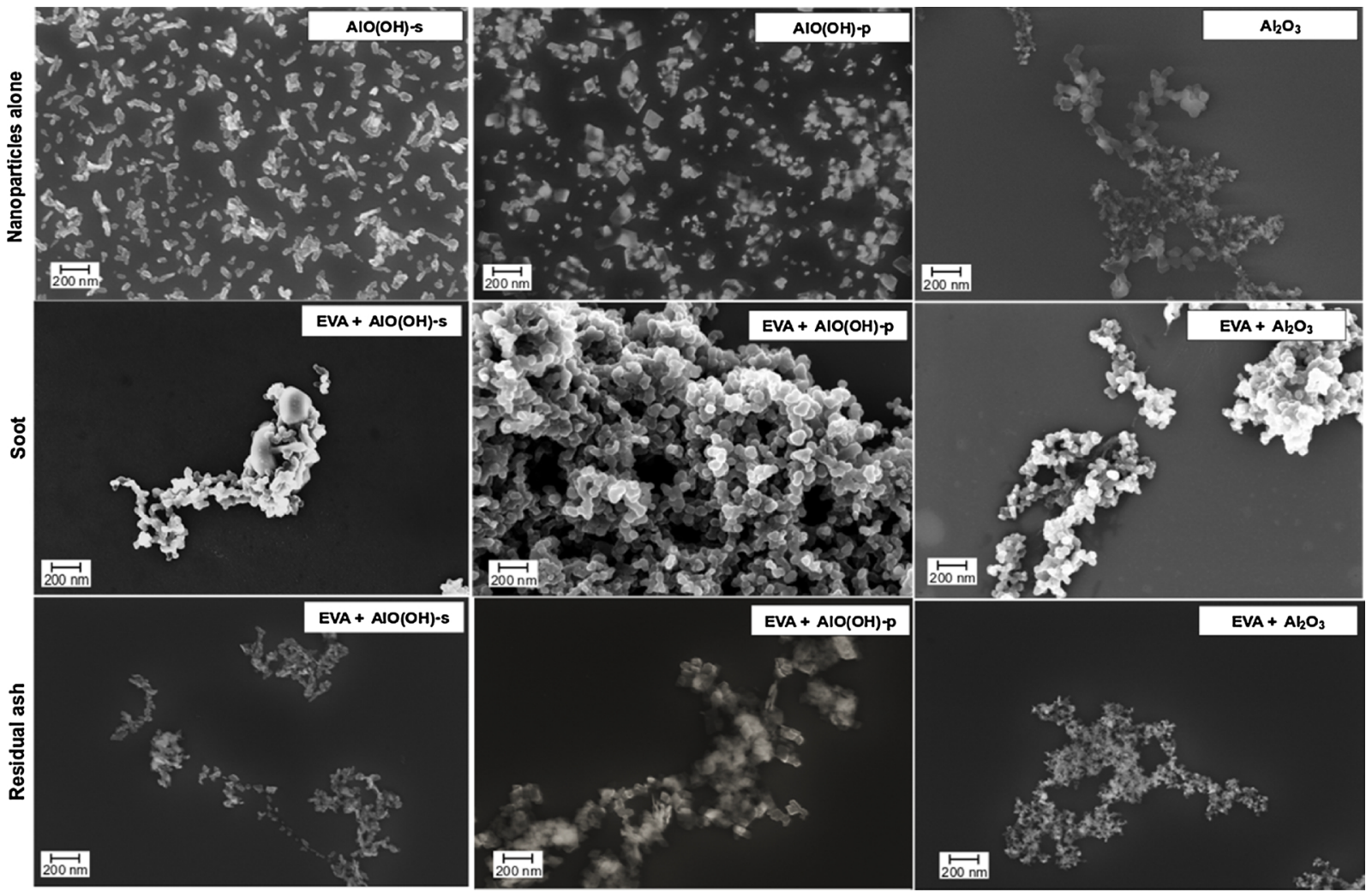

Fig. 4. Scanning electron microscopy (SEM) images of nanoparticles alone, soot and the residual ash after incineration for EVA-based nanocomposites.

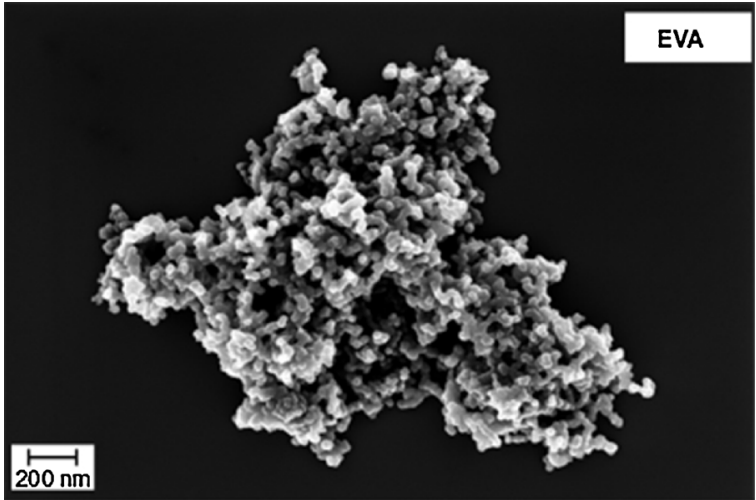

Fig. 5. Soot from EVA incineration.

(3\% wt. Fig. 3- versus $5 \mathrm{wt} . \%$ included in the formulations) in case of all boehmites and alumina.

The presence of nanoparticles has few influences on soot features. On the contrary, in the residual ash for all kinds of nanoparticles (boehmites and alumina) the presence of initial nanoparticles can be highlighted regarding the specific morphology and XRD spectra (Figs. 6 and 7). In EVA nanocomposites containing boehmites (Fig. 7), a fraction of isolated pristine nanoparticles is quite distinct in the residual ash, whatever the shape of boehmite nanoparticles $(\mathrm{AlO}(\mathrm{OH})-\mathrm{p}$ and $\mathrm{AlO}$ (OH)-s).

Even if nanoparticles are not detected in aerosol for the nanocomposite in incineration conditions, soot morphology is affected by their presence. The presence of nanoparticles in ash residue was also investigated by XRD analysis. The nanoparticle affects the residue morphology. Significant residual ash is generated with boehmites and alumina.

The particles and residue characterizations by XRD (Fig. 6) show the stability of alumina during heat treatment and the transformation of

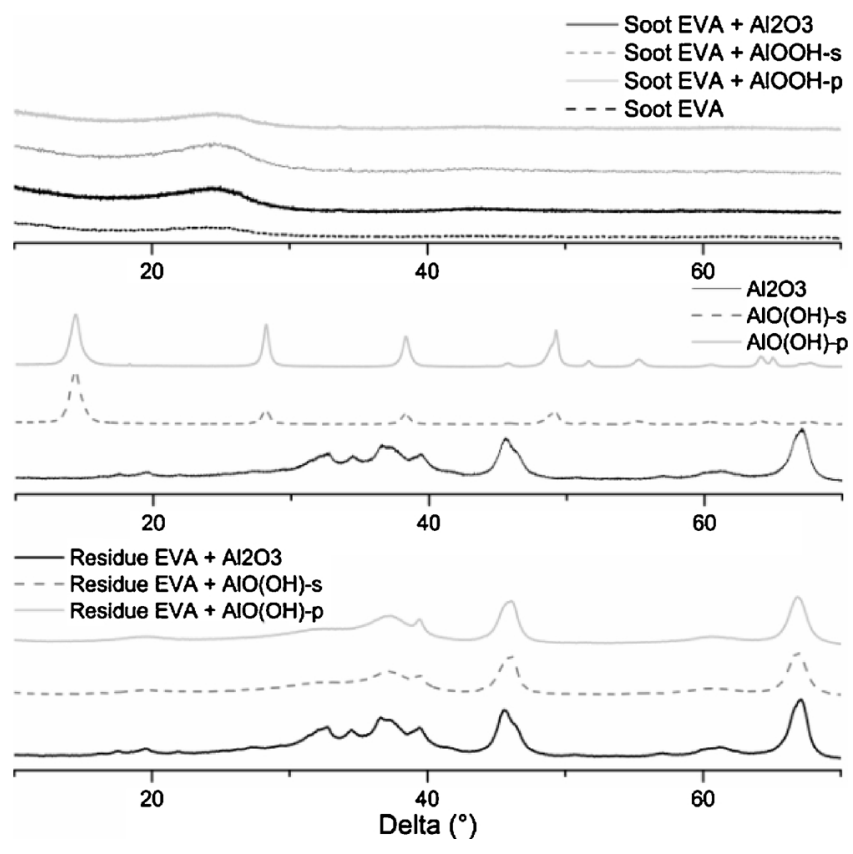

Fig. 6. XRD analysis of neat particles (left) and residues of composites (right)

boehmites in alumina. Indeed, it is knowing that the boehmites present a degradation temperature between $450^{\circ} \mathrm{C}-500^{\circ} \mathrm{C}$ and this degradation corresponds to the dehydroxylation of $\mathrm{AlO}(\mathrm{OH})$. The irradiation used in incineration simulation test $\left(75 \mathrm{~kW} / \mathrm{m}^{2}\right)$ is equivalent to $850{ }^{\circ} \mathrm{C}$, the boehmites are so exposed to a higher temperature than necessary to transform it in alumina. These analyses have demonstrated that the particle shape has no influence on the particles degradation pathway.

For each of the batches of nanoparticles prepared, size distribution were established and fitted by a statistical model (the Maximum- 

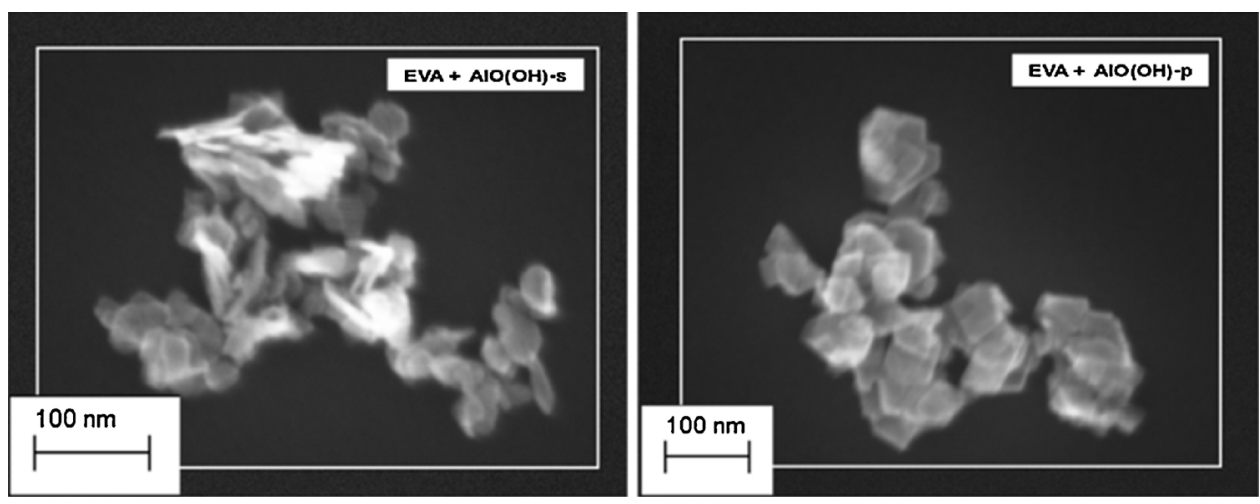

Fig. 7. Focus on residual ash from EVA containing boehmites ( $\mathrm{AlO}(\mathrm{OH})-\mathrm{p}$ and $\mathrm{AlO}(\mathrm{OH})-\mathrm{s})$.

Likelihood estimation) [27]. Around twenty images have been acquired and 200 particles have been selected and measured by the image analysis software developed by Delvallée [28]. As the particles are not always spherical, the measured diameter is an area-equivalent diameter, $\mathrm{D}_{\text {area-eq. }}$ Then, the mean diameter and the standard deviation were calculated."

Whatever the origin of soot (EVA based nanocomposites), images from SEM analysis and results from zeta potential measurements conduct to similar behavior with an equivalent diameter closed to $45 \mathrm{~nm}$ in average and an isoelectric point (noted IEP) around to 2 .

This seems that the EVA soot governs emission at high temperature. Even if residual ash from boehmites contained some similar shape nanoparticles (see Fig. 7), the chemistry is clearly modified with alumina formation (see Fig. 6). In contrast to soot, the equivalent diameter (Table 1) measured for residual ash is decreasing for $\mathrm{AlO}(\mathrm{OH})-\mathrm{p}$ and $\mathrm{Al}_{2} \mathrm{O}_{3}$, excepted for $\mathrm{AlO}(\mathrm{OH})$-s. In this last case, it should be due to absorption of residual carbon from EVA decomposition.

To go in depth, we investigated variation of the $\zeta$-potential measurements in order to investigate the effect of the morphology of nanoparticle and the coverage of EVA soot absorbed on different nanoparticles (Fig. 8). According to Gao et al. [29] the absorption of nanoparticle to pollutants is dependent on $\mathrm{pH}$. The adsorption onto a solid depends on the $\mathrm{pH}$ and at the $\mathrm{pH}$ at which the surface of nanoparticle become neutral (isoelectric point IP) particle tends to be agglomerated. Generally, $\mathrm{pH}$ could be one factor which can have an influence on the state of aggregation of nanoparticle under different conditions (temperature, coating...). As underlines Kosmulski in a recent review [37], the $\zeta$-potential is not only related to the type of material. Zêta potential could depend on the chemical and crystallographic composition, particle size, crystallinity, impurities, and the presence of thermodynamically unstable phases.

In our case, the boehmites nanoparticles (i.e. $\mathrm{AlO}(\mathrm{OH})$-s and $\mathrm{AlO}$ $(\mathrm{OH})$-p) exhibit a close zeta potential of $+50 \mathrm{mV}$ at natural $\mathrm{pH}$ of about 4. By adding $\mathrm{NaOH}$, the potential decreases gradually to a negative value of $-35 \mathrm{mV}$ at $\mathrm{pH} 12$ via an isoelectric point (IEP) at $\mathrm{pH} 10$. Alumina (i.e. $\mathrm{Al}_{2} \mathrm{O}_{3}$ ) has a natural $\mathrm{pH}$ of 5 with a positive zeta potential. By adding of $\mathrm{NaOH}$, the potential decreases gradually to reach a negative value of $-35 \mathrm{mV}$ at $\mathrm{pH} 12$ through an isoelectric point at $\mathrm{pH}$ 6.2.

Aerosols from EVA nanocomposites incineration of based on boehmites (i.e. $\mathrm{AlO}(\mathrm{OH})$-s and $\mathrm{AlO}(\mathrm{OH})-\mathrm{p})$ and alumina nanoparticles have a zeta potential close to $-45 \mathrm{mV}$ at the natural $\mathrm{pH}$ of soot which is around 7. By adding $\mathrm{NaOH}$ base, the potential decreases gradually to a negative value of $-60 \mathrm{mV}$ at $\mathrm{pH} 12$. The comparison of zeta potential profile show a similar behavior between pristine EVA and soot from EVA filled NP. These results suggest that the behavior of aerosols from incineration containing NP becomes similar to that of the EVA soot alone. That suggested the soot is a carbon-containing structure. The presence of NP does not cause changes in the surface charge of the soot. At acid $\mathrm{pH}$, the zeta potential is close to 0 . The repulsion due to the surface charge is non-existent and sedimentation of soot in an aqueous medium is maximal. It seems to demonstrate that the nanoparticles are not associated (or interact) with soot of particles from EVA incineration process. The fate of by-product generated by incineration highlights the important role of the matrix EVA thermal properties on the release of nanofillers in soot or in residual ash during end-of-life incineration. It is confirmed by the all the data analysis in previous section. It may be noticed that the zeta potential for residual ash is affected by the presence of nanoparticles and the evolution of the curve is close to this of pristine nanoparticles. Indeed, nanoparticles from boehmites are easily broken up and isolated from residual ash (see Fig. 7).

However, important changes are observed and summarized in the Table 2.

The toxicological responses were evaluated by dosing the LDH release assessing the damage of the cell membrane (Fig. 9).

Concerning the cytotoxicty level of the pristine nanofillers, two behaviours are observed when cells are incubated $24 \mathrm{H}$ with nanoparticles. Whatever the shape of boehmite nanoparticles ( $\mathrm{AlO}(\mathrm{OH})-\mathrm{p}$ and $\mathrm{AlO}(\mathrm{OH})-\mathrm{s})$, the $\mathrm{LDH}$ values are always at the same level by comparison with the negative control (i.e. macrophages incubated without nanoparticles). This result supports the conclusion that all boehmite nanofillers studied were not cytotoxic. By contrast, Alumina nanofillers showed a significant and moderate cytotoxic profile, but only for the higher dose used (i.e. $90 \mu \mathrm{g} / \mathrm{mL}$ ). Although, the biological outcome of the pristine nanofillers was clearly disparate, interestingly we noticed that the cytotoxicity level of the by-products obtained after the incineration process lead to a same toxicological behaviour whatever the Al-based nanocomposites (i.e. using boehmite or alumina nanofillers). Indeed, firstly our findings clearly demonstrated that the resulted

Table 1

Statistical parameter for estimation of the size distribution of nanoparticles measured on SEM Images.

\begin{tabular}{|c|c|c|c|c|c|c|c|c|c|c|}
\hline & \multicolumn{3}{|l|}{ Pristine NP } & \multicolumn{4}{|c|}{ Soot from EVA/NP } & \multicolumn{3}{|c|}{ Residues from EVA/NP } \\
\hline & $\mathrm{AlO}(\mathrm{OH})-\mathrm{s}$ & $\mathrm{AlO}(\mathrm{OH})-\mathrm{p}$ & $\mathrm{Al}_{2} \mathrm{O}_{3}$ & EVA alone & $\mathrm{AlO}(\mathrm{OH})-\mathrm{s}$ & $\mathrm{AlO}(\mathrm{OH})-\mathrm{p}$ & $\mathrm{Al}_{2} \mathrm{O}_{3}$ & $\mathrm{AlO}(\mathrm{OH})-\mathrm{s}$ & $\mathrm{AlO}(\mathrm{OH})-\mathrm{p}$ & $\mathrm{Al}_{2} \mathrm{O}_{3}$ \\
\hline $\begin{array}{l}\text { Mean diameter } \\
\text { Darea-eq. (nm) }\end{array}$ & 33.6 & 29.5 & 30.5 & 48.6 & 43.5 & 48.6 & 42 & 46.6 & 26.4 & $<10^{\mathrm{a}}$ \\
\hline Standard deviation $(\sigma)$ & 18.5 & 9.7 & 18.7 & 12.9 & 13.9 & 12.9 & 12.6 & 12.3 & 10.2 & a \\
\hline
\end{tabular}

${ }^{\text {a }}$ not measured. 

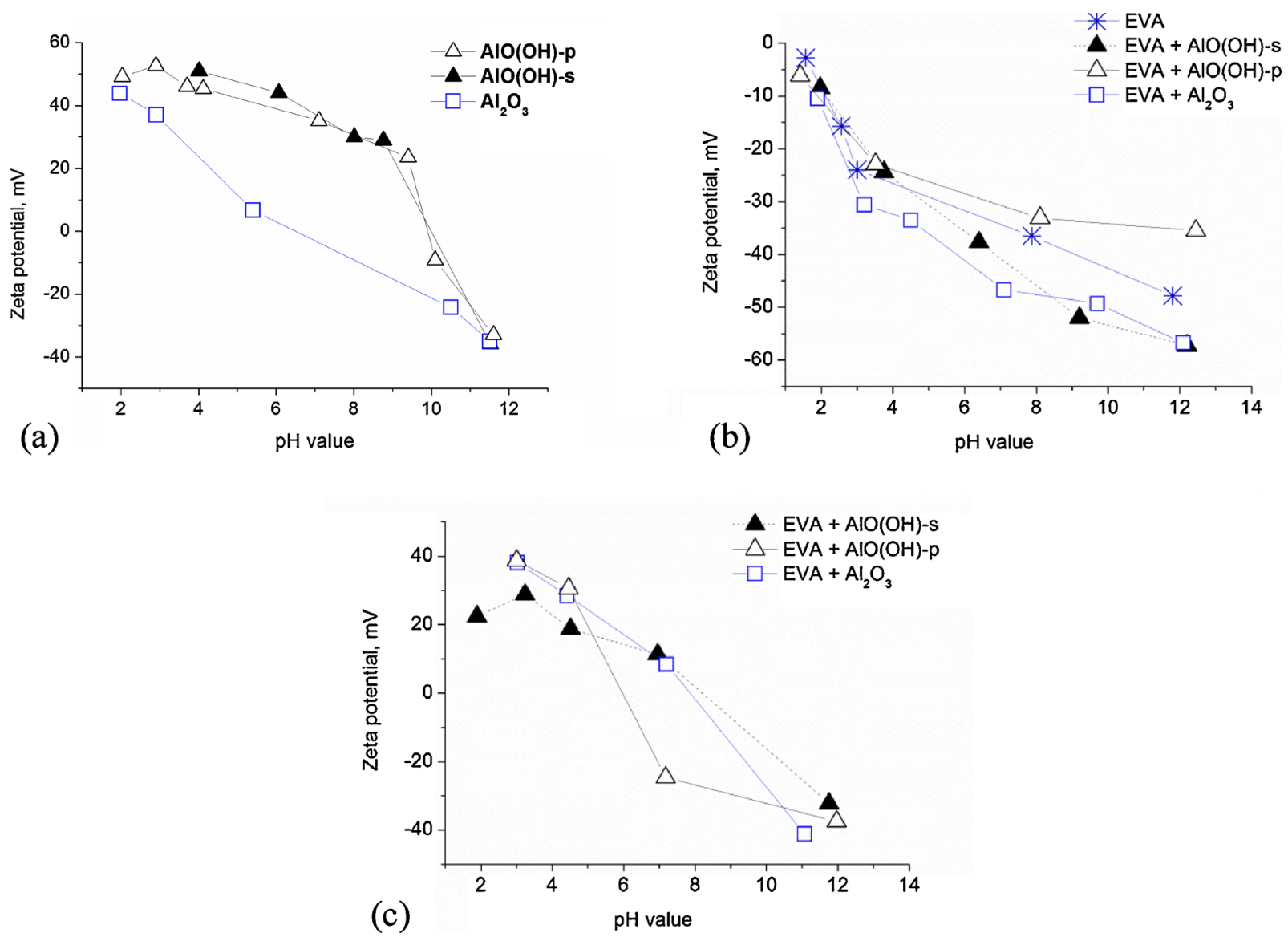

Fig. 8. Variation of Zeta potential as a function of $\mathrm{pH}$ in three different metal oxides. Zeta-potential reported for (a) nanoparticles alone, (b) soot from EVA nanocomposites and (c) residual ash from EVA nanocomposites.

residual ash of Al-based nanocomposites is not cytotoxic. On the contrary, the soot obtained after thermodegradation of Al-based nanocomposites showed a significant and moderate cytotoxic profile, but only for the higher dose used (i.e. $90 \mu \mathrm{g} / \mathrm{mL}$ ). In other words, the biological outcome confirms that the chemical transformation of pristine nanofillers during the incineration process (i.e. mainly the transformation of boehmite into alumina) lead to obtain similar hazard profile in by-products, although the cytotoxicological profile of the pristine nanofillers initially incorporated into the EVA matrix were disparate.

Indeed, the biological outcome confirms that the chemical transformation of pristine nanofillers during the incineration process (i.e. mainly the transformation of boehmite into alumina) lead to obtain similar hazard profile in by-products, although the cytotoxicological profile of the pristine nanofillers initially incorporated into the EVA matrix were disparate.

\section{Conclusion}

In summary, the LDH toxicological responses of pristine Al-based nanofillers (boehmites and alumina) are different. The boehmites were not cytotoxic contrary to alumina that shows a moderate cytotoxic profile. The data presented here clearly underline that the residual ash of Al-based nanocomposites are not cytotoxic. By contrast, we showed that soot resulting of Al-based nanocomposites is cytotoxic with no significant impact of the type of nanofillers (Boehmite versus Alumina). Thus the residual ash from incineration of Al-based nanocomposites can be re-used for road construction, or landfilled.

Enhanced, safer approaches by design apply to the design stage of the nanocomposites using nanoparticles less toxic during the production phase. However, during the end-of-life cycle, especially here incineration, nanoparticles that appeared "safe" at the production stage of

Table 2

Factors affecting the fate of nanoparticles from nanocomposites after incineration.

\begin{tabular}{|c|c|c|c|c|}
\hline & & \multicolumn{3}{|c|}{ Statistical analysis } \\
\hline & & $\mathrm{Al}$ & Morphology & Size \\
\hline \multirow[t]{3}{*}{ Pristine nanoparticles } & $\mathrm{AlO}(\mathrm{OH})-\mathrm{s}$ & $* * * *$ & Spherical & Around $30 \mathrm{~nm}$ \\
\hline & $\mathrm{AlO}(\mathrm{OH})-\mathrm{p}$ & $* * * *$ & Platelet & \\
\hline & $\mathrm{Al}_{2} \mathrm{O}_{3}$ & $* * * *$ & Spherical & \\
\hline \multirow[t]{3}{*}{ Soot } & $\mathrm{AlO}(\mathrm{OH})-\mathrm{s}$ & Ns & Spherical & Around $45 \mathrm{~nm}$ \\
\hline & $\mathrm{AlO}(\mathrm{OH})-\mathrm{p}$ & Ns & Spherical & \\
\hline & $\mathrm{Al}_{2} \mathrm{O}_{3}$ & ns & Spherical & \\
\hline \multirow[t]{3}{*}{ Residual ash } & $\mathrm{AlO}(\mathrm{OH})-\mathrm{s}$ & $* * *$ & Spherical & Value close to pristine nanoparticles \\
\hline & $\mathrm{AlO}(\mathrm{OH})-\mathrm{p}$ & $* * *$ & Spherical and Platelet & Value close to soot \\
\hline & $\mathrm{Al}_{2} \mathrm{O}_{3}$ & $* * *$ & Spherical & Value smaller than pristine nanoparticles \\
\hline
\end{tabular}




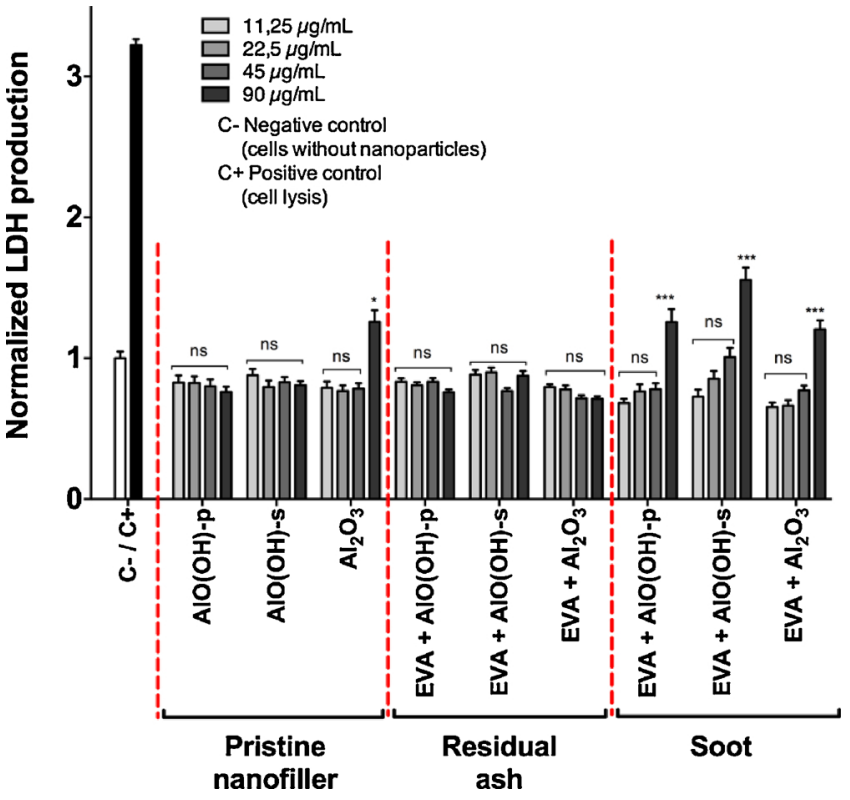

Fig. 9. Cytotoxicity of the 3 types of nanoparticles in residual ash, in soot was investigated using the LDH assay in RAW 264.7 macrophages. Results are means of 3 independent experiments. Negative control (noted C-): cells without nanoparticles. Positive control (noted C +): cells lysis. Significantly different from negative control $* * *$ : $<0.0001$ and $*$ : $<<0.05$, NS: not significantly different $(\mathrm{p}>0.05)$.

the nanocomposite (i.e. boehmite), may have physico-chemical transformations with a strong impact on the biological outcomes of soot. The factors that can influence the toxicological risk are linked to the physico-chemical parameters that can be modified during incineration process. The transformation of boehmites into alumina during the incineration process leads to obtain similar cytotoxicological profile in soot, whereas pristine boehmites appeared as safe.

These results lead to the conclusion that both flue gas and slag treatments will be affected by concerns about nanomaterials risks and hence, potential precautions will need to be taken in their subsequent treatment steps. That needs to develop analysis methods and tools to characterize the waste nanostructure.

\section{Conflicts of interest}

The authors report no conflicts of interest.

\section{Acknowledgements}

The authors are grateful to the French Environment and Energy Management Agency (ADEME) under grant $n^{\circ} 1506 \mathrm{C} 0054$ for the financial support provided to the NANOTOX'IN project. We acknowledge Simon Delcour for nanocomposites incineration. Thanks to Benjamin Gallard and Loic Dumazert from IMT Alès for technical support.

\section{References}

[1] M.E. Vance, T. Kuiken, E.P. Vejerano, S.P. McGinnis, Jr. Hochella, D. Rejeski, M.S. Hull, Nanotechnology in the real world: redeveloping the nanomaterial consumer products inventory, Beilstein J. Nanotechnol. 6 (2015) 1769-1780.

[2] E. Brun, M. Carrière, A. Mabondzo, In vitro evidence of dysregulation of blood-brain barrier function after acute and repeated/long-term exposure to $\mathrm{TiO} 2$ nanoparticles, Biomaterials 33 (2012) 886-896.

[3] National Science Foundation and U.S. Environmental Protection Agency (May 2003). Nanotechnology Grand Challenge in the Environment Research Planning Workshop, Session E: "Nanotechnology Implications in Health and the Environment".

[4] OECD Environment, Health and Safety Publications Series on the Safety of Manufactured Nanomaterials, (2018).
[5] No. 72, Toxicokinetics of Manufactured Na Nomaterials: Report From the OECD Expert Meeting, OECD ENV/JM/MO NO (2016) 24, (2016).

[6] F. Schrurs, D. Lison, More coherence and structure in the way research is conducted should be introduced in nanotoxicology, and all stakeholders must do their part, Nat. Nanotechnol. 7 (9) (2012) 546-548.

[7] ISO/TF, 13014: Nanotechnologies - Guidance on Physico-chemical Characterization of Engineered Nanoscale Materials for Toxicologic Assessment, (2012).

[8] OECD, Nanomaterials in Waste Streams - Current Knowledge on Risks and Impacts, 2016, (2016), https://doi.org/10.1787/9789264249752-en.

[9] L. Roes, M.K. Patel, E. Worrell, C. Ludwig, Preliminary evaluation of risks related to waste incineration of polymer nanocomposites, Sci. Total Environ. 417-418 (2012) 76-86.

[10] T. Walser, L.K. Limbach, R. Brogioli, E. Erismann, L. Flamigni, B. Hattendorf, M. Juchli, F. Krumeich, C. Ludwig, K. Prikopsky, M. Rossier, D. Saner, A. Sigg, S. Hellweg, D. Günther, W.J. Stark, Persistence of engineered nanoparticles in a municipal solid-waste incineration plant, Nat. Nanotechnol. 7 (2012) 520-524.

[11] M.-A. Marcoux, M. Matias, F. Olivier, G. Keck, Review and prospect of emerging contaminants in waste - key issues and challenges linked to their presence in waste treatment schemes: general aspects and focus on nanoparticles, Waste Manag. 33 (2013) 2147-2156.

[12] L. Roes, M.K. Patel, E. Worrell, C. Ludwig, Preliminary evaluation of risks related to waste incineration of polymer nanocomposites, Sci. Total Environ. 417-418 (2012) 76-86.

[13] G.A. Sotiriou, D. Singh, F. Zhang, M.G. Chalbot, E. Spielman-Sun, L. Hoering, I.G. Kavouras, G.V. Lowry, W. Wohlleben, P. Demokritou, Thermal decomposition of nano-enabled thermoplastics: possible environmental health and safety implications, J. Hazard. Mater. 305 (2016) 87-95.

[14] E.P. Vejerano, E.C. Leon, A.L. Holder, L.C. Marr, Characterization of particle emissions and fate of nanomaterials during incineration, Environ. Sci. Nano 1 (133) (2014).

[15] D. Singh, G.A. Sotiriou, F. Zhang, J. Mead, D. Bello, W. Wohlleben, P. Demokritou, End-of-life thermal decomposition of nano-enabled polymers: effect of nanofiller loading and polymer matrix on by-products, Environ. Sci. Nano 3 (2016) 1293-1305.

[16] G. Ounoughene, O. Lebihan, B. Debray, C. Chivas-Joly, C. Longuet, A. Joubert, J. M. Lopez-Cuesta, L. Le Coq, Thermal disposal of waste containing nanomaterials: first investigations on a methodology for risk management, J. Phys. Conf. Ser. 838 (1) (2017) 1012024.

[17] C. Chivas-Joly, C. Motzkus, E. Guillaume, S. Ducourtieux, L. Saragoza, D. Lesenechal, J.-M. Lopez-Cuesta, C. Longuet, R. Sonnier, B. Minisini, Influence of carbone nanotubes on fire behaviour and aerosols emitted during combustion of thermoplastics, Fire Mater. 38 (1) (2014) 46-62.

[18] C. Chivas-Joly, C. Longuet, C. Motzkus, J.M. Lopez-Cuesta, Influence of the composition of PMMA nanocomposites on gaseous effluents emitted during combustion, Polym. Degrad. Stab. 113 (2015) 197-207.

[19] A.A. Stec, J. Rhodes, Smoke and hydrocarbon yields from fire retarded polymer nanocomposites, Polym. Degrad. Stab. 96 (3) (2011) 295-300.

[20] J-M. Lopez-Cuesta, C. Longuet, C. Chivas-Joly, Health and environmental safety of nanomaterials: Polymer nancomposites and other materials containing nanoparticles. Edited by J Njuguna, Cranfield University, UK, K Pielichowski, Cracow University of Technology, Poland and H Zhu, Cranfield University, UK, Woodhead Publishing Series in Composites Science and Engineering No. 49 (2013).

[21] J. Rhodes, C. Smith, A.A. Stec, Characterisation of soot particulates from fire retarded and nanocomposite materials, and their toxicological impact, Polym. Degrad. Stab. 96 (2011) 277-284.

[22] G. Ounoughene, O. Le Bihan, C. Chivas-Joly, C. Motzkus, C. Longuet, B. Debray, A. Joubert, L. Le Coq, J.-M. Lopez-Cuesta, Behavior and fate of halloysite nanotubes (HNTs) when incinerating PA6/HNTs Nanocomposite, Environ. Sci. Technol. 49 (9) (2015) 5450-5457.

[23] G. Ounoughene, Etude des émissions liées à la décomposition thermique de nanocomposites: application à l'incinération, PhD Ecole des Mines de Nantes, (2015).

[24] D. Singh, G.A. Sotiriou, F. Zhang, J. Mead, D. Bello, W. Wohlleben\&, P. Demokritou, End-of-life thermal decomposition of nano-enabled polymers: effect of nanofillerloading and polymer matrix on by-products, Environ. Sci. Nano (2016), https://doi.org/10.1039/C6EN00252H.

[25] D. Tran, D. Fleury, D. Venditti, S. Durecu, A. Joubert, The NANOFlueGas Project: Characterization and Reduction of Particulate Emissions From the Incineration of Wastes Containing Manufactured Nanomaterials, International Congress on Safety of Engineered Nanoparticles and Nanotechnologies (SENN2012), Helsinki, Finland, 2012 Oct ineris-00971075.

[26] L. Leclerc, D. Boudard, J. Pourchez, V. Forest, O. Sabido, V. Bin, S. Palle, O.P. Grosseau, D. Bernache, M. Cottier, Quantification of microsized fluorescent particles phagocytosis to a better knowledge of toxicity mechanisms, Inhal. Toxicol. 22 (2010) 1091-1100.

[27] L. Leclerc, W. Rima, D. Boudard, J. Pourchez, V. Forest, V. Bin, P. Mowat, P. Perriat, O. Tillement, P. Grosseau, D. Bernache-Assollant, M. Cottier, Size of submicrometric and nanometric particles affect cellular uptake and biological activity of macrophages in vitro, Inhal. Toxicol. 24 (2012) 580-588.

[28] D. Mott, B. Cotts, S. Lim I-Im, Size determination of nanoparticles based on tappingmode atomic force microscopy measurements, J. Scanning Probe Microsc. 3 (2008) 1-8, https://doi.org/10.1166/jspm.2008.001.

[29] A. Delvallée, N. Feltin, S. Ducourtieux, et al., Direct comparison of AFM and SEM measurements on the same set of nanoparticles, Meas. Sci. Technol. 26 (15) (2015) 085601, , https://doi.org/10.1088/0957-0233/26/8/085601. 